\title{
Oscillations in cytoplasmic free calcium concentration in human pancreatic islets from subjects with normal and impaired glucose tolerance
}

\author{
H. Kindmark ${ }^{1}$, M. Köhler ${ }^{1}$, P. Arkhammar ${ }^{1}$, S. Efendic ${ }^{1}$, O. Larsson ${ }^{1}$, S. Linder ${ }^{2}$, T. Nilsson ${ }^{1}$, P.-O. Berggren ${ }^{1}$ \\ ${ }^{1}$ The Rolf Luft Center for Diabetes Research, Department of Molecular Medicine, Karolinska Institute, Karolinska Hospital, \\ Stockholm, Sweden \\ ${ }^{2}$ Department of Surgery, Södersjukhuset, Stockholm, Sweden
}

Summary Plasma insulin levels in healthy subjects oscillate and non-insulin-dependent diabetic patients display an irregular pattern of such oscillations. Since an increase in cytoplasmic free $\mathrm{Ca}^{2+}$ concentration $\left(\left[\mathrm{Ca}^{2+}\right]_{i}\right)$ in the pancreatic beta cell is the major stimulus for insulin release, this study was undertaken to investigate the dynamics of electrical activity, $\left[\mathrm{Ca}^{2+}\right]_{\mathrm{i}}$-changes and insulin release, in stimulated islets from subjects of varying glucose tolerance. In four patients it was possible to investigate more than one of these three parameters. Stimulation of pancreatic islets with glucose and tolbutamide sometimes resulted in the appearance of oscillations in $\left[\mathrm{Ca}^{2+}\right]_{\mathrm{i}}$, lasting 2-3 min. Such oscillations were observed even in some islets from patients with impaired glucose tolerance. In one islet from a diabetic patient there was no response to glucose, whereas that islet displayed $\left[\mathrm{Ca}^{2+}\right]_{i}$-oscillations in response to tolbutamide, suggesting that sulphonylurea treatment can mimic the complex pattern of glucose-in- duced $\left[\mathrm{Ca}^{2+}\right]_{i}$-oscillations. We also, for the first time, made patch-clamp recordings of membrane currents in beta-cells in situ in the islet. Stimulation with glucose and tolbutamide resulted in depolarization and appearance of action potentials. The islet preparations responded to stimulation with a number of different secretagogues with release of insulin. The present study shows that human islets can respond to stimulation with glucose and sulphonylurea with oscillations in $\left[\mathrm{Ca}^{2+}\right]$, which is the signal probably underlying the oscillations in plasma insulin levels observed in healthy subjects. Interestingly, even subjects with impaired glucose tolerance had islets that responded with oscillations in $\left[\mathrm{Ca}^{2+}\right]_{i}$ upon glucose stimulation, although it is not known to what extent the response of these islets was representative of most islets in these patients. [Diabetologia (1994) 37: 1121-1131]

Key words Islets of Langerhans, glucose, tolbutamide, $\left[\mathrm{Ca}^{2+}\right]_{\mathrm{i}}$-oscillations, insulin secretion.
Since the availability of viable human pancreatic islet tissue is restricted, only a few studies concerning their beta-cell stimulus-secretion coupling have been carried out. Recently, we provided the first report of

Received: 14 February 1994 and in revised form: 15 July 1994

Corresponding author: Dr. P.-O. Berggren, The Rolf Luft Center for Diabetes Research, Department of Molecular Medicine, Karolinska Institute, Karolinska Hospital, S-171 76 Stockholm, Sweden

Abbreviations: $\left[\mathrm{Ca}^{2+}\right]_{i}$, Cytoplasmic free $\mathrm{Ca}^{2+}$; NIDDM, noninsulin-dependent diabetes mellitus; DMSO, dimethylsulphoxide; PC, pancreatic cancer. measurements of changes in cytoplasmic free $\mathrm{Ca}^{2+}$ $\left(\left[\mathrm{Ca}^{2+}\right]_{\mathrm{i}}\right)^{1}$ in response to several different stimuli [1] in human pancreatic islets. Subsequently similar results have been obtained by Misler et al. [2] who also registered stimulated electrical activity from human islet cell clusters. The results from those studies are compatible with data obtained in pancreatic islets from rodents. Studies using mouse islets have demonstrated the presence of both slow and fast $\left[\mathrm{Ca}^{2+}\right]_{i}$-oscillations during glucose stimulation [3]. The slow oscillations have a frequency of $0.5 \pm 0.2 \mathrm{~min}^{-1}$, whereas the frequency of fast oscillations is $3.1 \pm 0.8$ $\min ^{-1}[3]$. The present study is an extension of previous work and presents results from further investigations into the dynamics of the $\left[\mathrm{Ca}^{2+}\right]_{\mathrm{i}}$-responses to 
Table 1. The table describes each patient included in the present study with regard to age, sex, clinical diagnosis, fasting blood sugar and glucose tolerance

\begin{tabular}{llllll}
\hline Patient & $\begin{array}{l}\text { Age } \\
\text { (years) }\end{array}$ & $\begin{array}{l}\text { Sex } \\
\text { (male/female) }\end{array}$ & Diagnosis & $\begin{array}{l}\text { Fasting blood glucose } \\
\text { (mmol/l) }\end{array}$ & Glucose tolerance \\
\hline 1 & 70 & female & PC & 6.0 & Impaired \\
2 & 79 & female & PC & 5.5 & Normal \\
3 & 63 & female & PC & 4.7 & Unknown \\
4 & 57 & female & PC & 5.1 & Diabetic \\
5 & 73 & female & PC & 4.9 & Unknown $^{\text {Diabetic }}$ \\
6 & 83 & male & PC & 8.6 & Normal $^{\mathrm{a}}$ \\
7 & 75 & female & PC & 5.6 & Diabetic \\
8 & 80 & female & PC & 8.7 & Impaired \\
9 & 62 & female & PC & 4.6 & . \\
\hline
\end{tabular}

PC, Pancreatic cancer. ${ }^{a}$ A glucose tolerance test was not performed on patients with a fasting blood glucose in the diabetic range

various stimuli in human pancreatic islets. In particular, we were interested in determining if the oscillations in $\left[\mathrm{Ca}^{2+}\right]_{\mathrm{i}}$ and electrical activity, which have been observed in rodent islets [3, 4], also occur in human tissue. In view of the many reports of oscillating levels of plasma insulin in human subjects $[5,6]$, and the well-established model for stimulus-secretion coupling in which electrical activity and an increase in $\left[\mathrm{Ca}^{2+}\right]_{i}$ directly regulates insulin release [7], it seems reasonable to assume that oscillations in electrical activity and $\left[\mathrm{Ca}^{2+}\right]_{\mathrm{i}}$ in human pancreatic islets do occur. The possible physiological significance of oscillations in plasma insulin levels is great, since intravenously administered insulin has been shown to have a greater hypoglycaemic effect when pulsed $[8$, $9]$, and thus oscillatory activity at the level of $\left[\mathrm{Ca}^{2+}\right]_{\mathrm{i}}$ in islets, possibly the signal giving rise to pulsatile insulin secretion, is also of major interest. It has been shown in the dog that pulsatile secretion of insulin is a feature of the pancreas per se [10]. Since it has been suggested that a disturbed pattern of oscillatory insulin secretion could be an early phenomenon in non-insulin-dependent diabetes mellitus (NIDDM) [11], it was of interest also to study the dynamics of glucose-induced $\left[\mathrm{Ca}^{2+}\right]_{\mathrm{i}}$-increases in islets from patients with impaired glucose tolerance, a population at risk for developing NIDDM [12].

\section{Subjects, materials and methods}

All reagents were of analytical grade and Millipore-water was used. Bovine serum albumin fraction V and Fura-2/acetoxymethylester were from Sigma, (St. Louis, Mo., USA). Collagenase was from Boehringer Mannheim, Mannheim, Germany).

Media. The basal medium used for preparation of islets as well as for experiments was a HEPES buffer, $\mathrm{pH} 7.4$, with $\mathrm{Cl}^{-}$as the sole anion [13], containing 1.28 or $2.56 \mathrm{mmol} / / \mathrm{Ca}^{2+}$ and $1 \mathrm{mg} /$ $\mathrm{ml}$ bovine serum albumin.

Patients and preparation of islets. Pancreatic tissue was obtained from patients admitted to hospital because of painless jaundice, weight loss and fatigue. Each patient was investigated with an ultrasound scan of the abdomen and percutaneous transhepatic cholangiography. Patients with obstruction of the common bile duct, presumed to be caused by cancer of the pancreatic head-region, were preoperatively treated with a percutaneous transhepatically placed endoprosthesis in order to restitute bile flow to the gut. Surgery was performed 45 weeks after placement of the endoprosthesis. Table 1 shows the characteristics of the different patients included in the present study.

The operation on each patient was intended to be curative and the resected structures comprised the cephalic portion of the pancreas en bloc with the duodenum, according to Whipple. The time lost during transportation of the pancreatic tissue from the operating theater to the laboratory was approximately $20-30 \mathrm{~min}$.

Pancreatic islets were prepared essentially as has been previously described [1]. Briefly, a specimen, macroscopically free from tumour tissue, was obtained from the resected part of the pancreas and put in cold RPMI 1640 culture medium. Fibrotic and adipose tissue was removed from the pancreatic specimen under a dissection microscope and the specimen was then minced into 2-4 mm pieces. After collagenase digestion, single pancreatic islets were picked with the aid of a dissection microscope, using a braking pipette. Many islets had to be cleaned of surrounding exocrine pancreatic tissue using microdissection. Each isolation yielded from 5 to 50 presumed islets, which were then cultured for 1-5 days in RPMI 1640 medium supplemented with $10 \%$ fetal bovine serum, $100 \mathrm{IU}$ penicillin, $100 \mu \mathrm{g} / \mathrm{ml}$ streptomycin and $60 \mu \mathrm{g} / \mathrm{ml}$ gentamycin. The culture medium contained $11 \mathrm{mmol} / \mathrm{l}$ glucose, except in the case of the islets from patient 4 in the present study, as is indicated in the relevant figure legend. Experiments on the pancreatic islets were generally carried out the day after isolation. Exceptions to this rule are indicated in the relevant figure legends. The aim of the study was to measure electrical activity, $\left[\mathrm{Ca}^{2+}\right]_{\mathrm{i}}$-changes and insulin release in the islets from each individual, but due to the scarcity of the material it was not possible to measure each parameter for each case. Furthermore, despite the fact that the data included in the present study were collected over a period of 2 years, the limited number of patients available in the Stockholm area during this time was insufficient to draw any general conclusions about the responses of islets from subjects of varying glucose tolerance. This study should thus be viewed essentially as a collection of individual case reports. The present study was approved by the local ethical committee.

Measurements of $\left[\mathrm{Ca}^{2+}\right]_{i .}$. Islets were incubated in basal medium containing $3 \mathrm{mmol} / \mathrm{l}$ glucose and $2 \mu \mathrm{mol} / \mathrm{l} \mathrm{Fura-2/AM}$ for $1 \mathrm{~h}$ at $37^{\circ} \mathrm{C}$. Single islets were then transferred to an open perifusion chamber as previously described [14]. The medium flow 
A

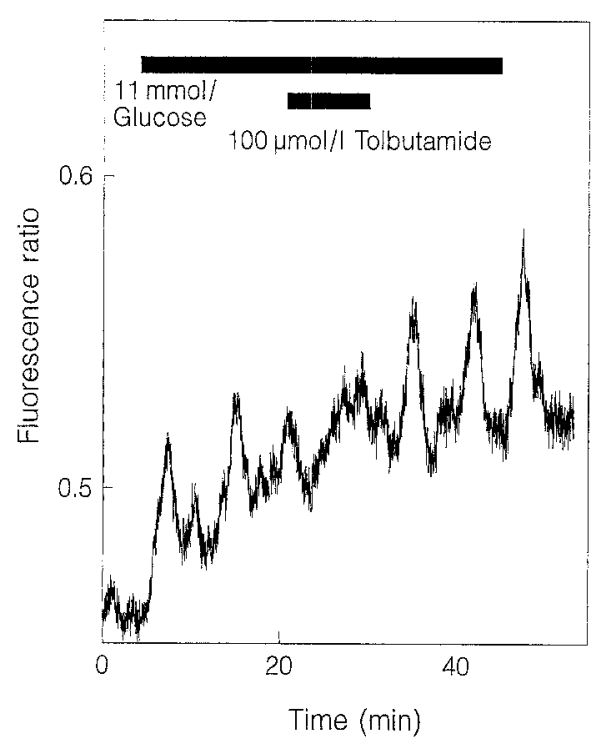

B

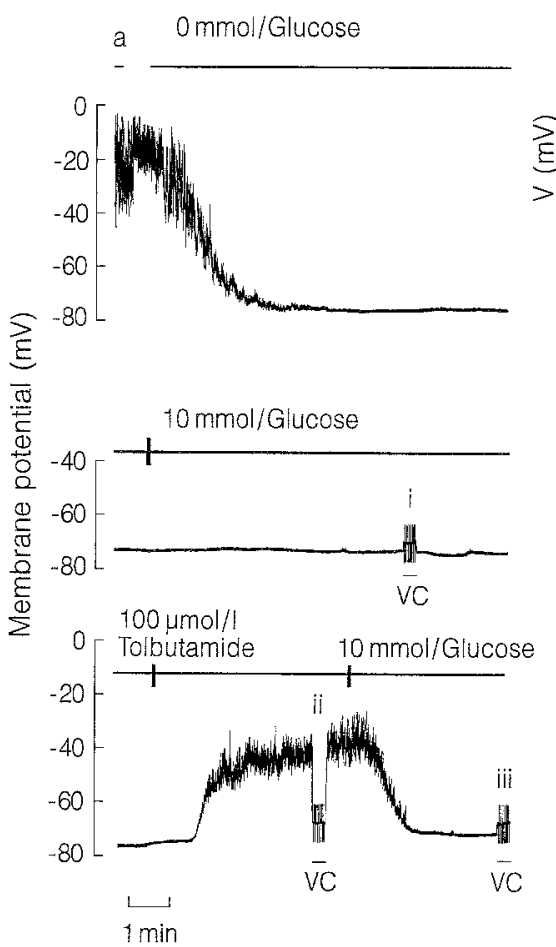

C

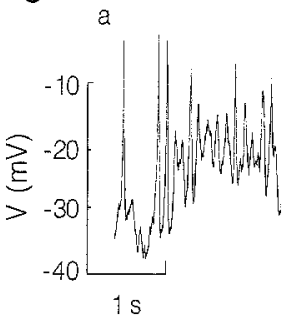

D

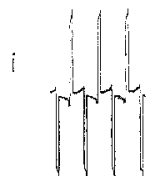

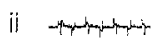

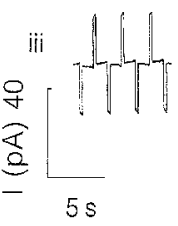

Fig. 1A-D. Effects of glucose and tolbutamide on $\left[\mathrm{Ca}^{2+}\right]_{\mathrm{i}}$ and membrane potential in islets from patient 1 , who had impaired glucose tolerance. A. Medium glucose concentration is increased from 3 to $11 \mathrm{mmol} / \mathrm{l}$. Addition of $100 \mu \mathrm{mol} / \mathrm{l}$ tolbutamide has little effect on $\left[\mathrm{Ca}^{2+}\right]_{i}$. The "fluorescence ratio" shown in this figure corresponds to $\left[\mathrm{Ca}^{2+}\right]_{\mathrm{i}}$. B. Whole-cell membrane current-voltage recordings, employing the perforated patch configuration of the patch-clamp technique, most likely from a beta-cell in situ in a pancreatic islet from the same patient. The membrane potential recording shows action potentials at the start of the experiment, probably due to the fact that the islet was incubated in medium containing $11 \mathrm{mmol} / \mathrm{l}$ glucose immediately prior to the experiment. The

was $200 \mu 1 \mathrm{~min}^{-1}$ and was controlled by a peristaltic pump (Ismatec). The chamber was placed in a holder on the stage of an inverted epifluorescence microscope (Zeiss, Axiovert $35 \mathrm{M}$; Oberkochen, Germany). Fura-2 fluorescence was measured at $37^{\circ} \mathrm{C}$, using a SPEX fluorolog-2 CM1T11I system, allowing fluorometry using two excitation wavelengths. The excitation wavelengths ( 340 and $380 \mathrm{~nm}$ ) were generated by two monochromators and emitted light was collected through a 510-nm filter inside the microscope. One 340/380 ratio was obtained each second. By using a 40x/0.75 NA objective and by changing the diameter of a variable diaphragm in the microscope, it was possible to select and measure from a single islet. Data from all measurements are expressed as 340/380 ratios.

Patch-clamp experiments. The perforated patch configuration of the patch-clamp technique $[15,16]$ was used. Pipettes were pulled from borosilicate glass, coated with Sylgard resin (Dow Corning Midland, Michigan, USA) near the tips, fire-polished and had resistances between 4 and $6 \mathrm{M} \Omega$. Current and voltage were recorded using an Axopatch 200 patch-clamp amplifier (Axon Instruments Inc. Foster City, CA, USA). During the experiments, the current and voltage signals were stored using a VR-100A digital recorder (Instrutech Corp., New York, NY, action potentials subside in the absence of glucose. Subsequent restimulation with glucose is without effect. Addition of $100 \mu \mathrm{mol} / \mathrm{l}$ tolbutamide results in depolarization of the plasma membrane. C. Expanded voltage-recording segment from B. This segment is indicated by the letter a. Note time-scale. $\mathbf{D}$. Whole-cell currents from the same cell at time points indicated by i-iii. $\mathrm{K}_{\mathrm{ATP}}$-channel currents recorded by alternating clamps of the cell membrane potential at -60 or $-80 \mathrm{mV}$ from a holding potential of $-70 \mathrm{mV}$. The lack of effect of $10 \mathrm{mmol} / \mathrm{l}$ glucose is reflected by the amplitude of the recorded current through the $\mathrm{K}_{\mathrm{ATP}}$-channels (i). After addition of tolbutamide this current is completely inhibited (ii), but it reappears after tolbutamide stimulation is discontinued (iii)

USA) and a high-resolution video cassette recorder (JVC, Yokohama, Japan). The extracellular solution contained (in mmol/l): $138 \mathrm{NaCl}, 5.6 \mathrm{KCl}, 1.2 \mathrm{MgCl}_{2}, 2.6 \mathrm{CaCl}_{2}$, and $5 \mathrm{Hepes}$ ( $\mathrm{pH} 7.4$ with $\mathrm{NaOH}$ ). The pipette solution consisted of (in mmol/l): $10 \mathrm{KCl}, 76 \mathrm{~K}_{2} \mathrm{SO}_{4}, 10 \mathrm{NaCl}, 1 \mathrm{MgCl}_{2}$ and 10 Hepes$\mathrm{NaOH}, \mathrm{pH} 7.35$ and $50 \mu \mathrm{g} / \mathrm{ml}$ nystatin or amphotericin B, dissolved in dimethylsulphoxide (DMSO). The final concentration of DMSO was $0.1 \%$. The bath had a volume of $0.4 \mathrm{ml}$ and was perfused at a rate of $4 \mathrm{ml} / \mathrm{min}$. Test compounds were added to the perfusion medium. Studies were done at $30-34^{\circ} \mathrm{C}$.

The whole-cell current signal was filtered at $1000 \mathrm{~Hz},(-3$ $\mathrm{dB}$ value), by using an 8-pole Bessel filter (Frequency Devices, Haverhill, MA, USA). Figures were made by plotting segments of the records with a chart recorder, scanning the segments using an HP scanner and incorporating them into a graphics software program. When patch-clamp recordings were made from cells in situ, the human islet was held in place by a separate suction pipette.

Measurement of insulin release. The kinetics of insulin release were studied by perifusing human islets mixed with Bio-Gel P4 polyacrylamide beads (Bio-Rad, Richmond, CA, USA) in a $0.5 \mathrm{ml}$ column at $37^{\circ} \mathrm{C}[17,18]$. The flow rate was approxi- 
A

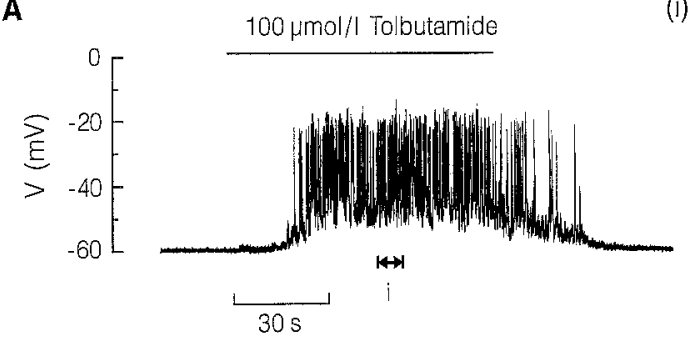

(i)

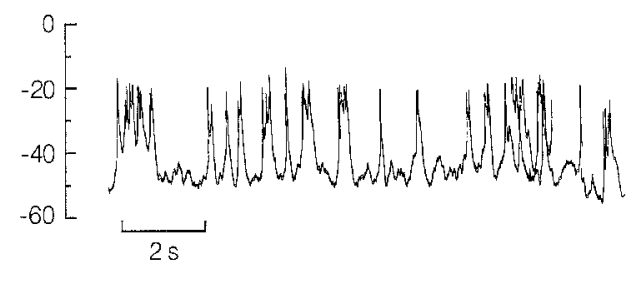

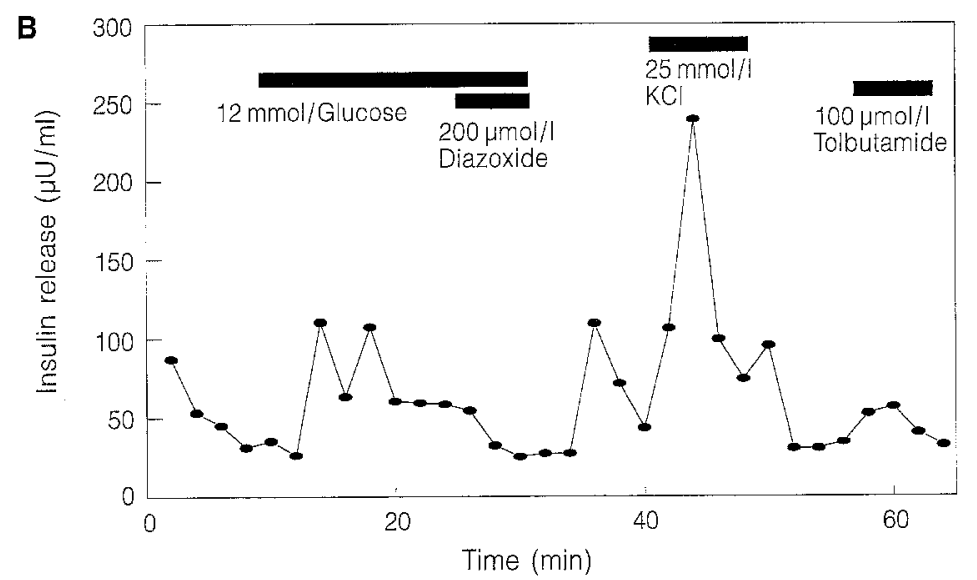

Fig. 2A, B. Effects of secretagogue stimulation on membrane potential and insulin release in islets from patient 2 , who had normal glucose tolerance. A. Whole-cell membrane potential recording, employing the perforated patch configuration of the patch-clamp technique, probably from a beta-cell in situ in a pancreatic islet. The experiment shows the effect of $100 \mu \mathrm{mol} / \mathrm{l}$ tolbutamide. The effect is reversible upon discontinuation of the sulphonylurea stimulation. (i) represents an expanded voltage-recording segment taken from the indicated

portion of the graph in A. B. Dynamics of insulin release from 25 islets. An increase of insulin release is caused by $12 \mathrm{mmol} / \mathrm{l}$ glucose, peaking at $219 \%$ of the average insulin release during the first $10 \mathrm{~min}$. Addition of $200 \mu \mathrm{mol} / 1$ diazoxide attenuates hormone release. After removal of diazoxide there is a brief period of stimulated insulin release. Depolarization of the islets with $25 \mathrm{mmol} / 1 \mathrm{KCl}$ results in a marked increase in insulin release. Tolbutamide has only a marginal effect. This experiment was performed 3 days after isolation of the islets

mately $250 \mu \mathrm{l} / \mathrm{min}$ and $2 \mathrm{~min}$ fractions were collected and analysed for insulin radioimmunologically, using crystalline human insulin as a reference.

In one experiment islets were incubated for $60 \mathrm{~min}$ in $300 \mu \mathrm{l}$ of basal medium, five islets per tube and three tubes per group, during continuous shaking at $37^{\circ} \mathrm{C}$. The basal buffer was then removed and replaced with the same volume of buffer containing an insulin secretagogue and the islets were further incubated for $60 \mathrm{~min}$. The stimulating buffer was also removed and both basal and stimulatory buffers were analysed for insulin content radioimmunologically.

\section{Results}

Patient 1. This patient had impaired glucose tolerance. Figure $1 \mathrm{~A}$ shows that an islet from patient 1 was still able to respond with slow oscillations in $\left[\mathrm{Ca}^{2+}\right]_{\mathrm{i}}$ in response to glucose stimulation. The oscillations had a 2-3 min duration. In Figure $1 B$ it can be seen that a beta cell in an islet from this patient was depolarized and displayed action potentials (Fig. 1C) immediately after being removed from the culture medium, which contained $11 \mathrm{mmol} / 1$ glucose. Hence, patient 1 had at least some islets that could respond to glucose stimulation. When glucose stimulation was discontinued, action potentials subsided.
When the islet was restimulated with $10 \mathrm{mmol} / \mathrm{l} \mathrm{glu}$ cose, however, there was no change in membrane potential. Possibly, the perforated-patch configuration had disturbed the signal-transduction pathways of the cell. Subsequent tolbutamide-stimulation did elicit depolarization and action potentials, an effect which was reversible. The action of the sulphonylurea compound on the $K_{A T P}$-channel is shown in Figure $1 \mathrm{D}$ (ii and iii). It should be noted that the experiments in Figure $1 \mathrm{~A}$ and $\mathrm{B}$ were carried out on two different islets, that, although from the same patient, do not necessarily respond in the same manner to similar stimuli. This explains why an oscillatory response to glucose is observed in Figure $1 \mathrm{~A}$, but not in $\mathrm{B}$. Also, the experiments in Figure $1 \mathrm{~A}$ and $\mathrm{B}$ were carried out at slightly different temperatures, which could influence the mechanisms generating oscillations. Furthermore, oscillations in electrical activity is not the only possible mechanism regulating oscillations in $\left[\mathrm{Ca}^{2+}\right]_{\mathrm{i}}$. Fluctuations in the $\mathrm{Ca}^{2+}$-extrusion processes could also give rise to oscillations in $\left[\mathrm{Ca}^{2+}\right]_{\mathrm{i}}$.

Patient 2. This patient had normal glucose tolerance. Figure 2 A shows that a beta cell in an islet from pa- 
A

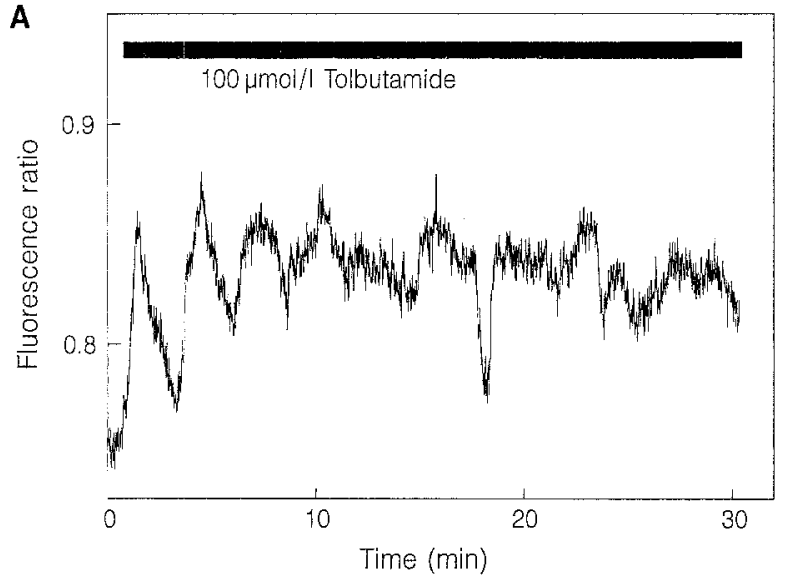

B

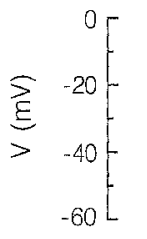

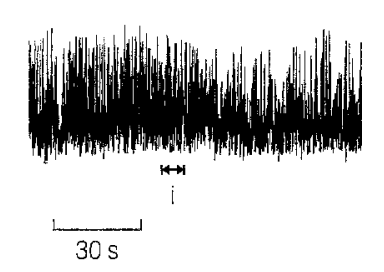

(i)

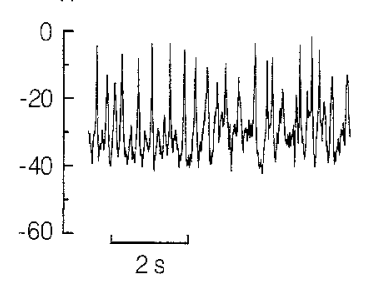

Fig.3A, B. Effect of tolbutamide and glucose stimulation on $\left[\mathrm{Ca}^{2+}\right]_{i}$ and membrane potential in islets from patient 3 , who had unknown glucose tolerance, but normal fasting blood glucose.

A. Islet stimulated with $100 \mu \mathrm{mol} / \mathrm{l}$ tolbutamide. The "fluorescence ratio" in this figure corresponds to $\left[\mathrm{Ca}^{2+}\right]_{\mathrm{i}}$. Previous stimulation of this islet with glucose resulted in a minute increase in $\left[\mathrm{Ca}^{2+}\right]_{\mathrm{i}}$ (data not shown).

B. Whole-cell membrane potential recording, employing the perforated patch configuration of the patch-clamp technique. Effect of $15 \mathrm{mmol} / \mathrm{l}$ glucose on the membrane potential of a putative beta cell. (i) Represents an expanded voltage-recording segment taken from the indicated portion of the graph in $B$ tient 2 responded with depolarization and action potentials upon exposure to tolbutamide. As can be seen in the expanded segment from Figure 2A, (i), the action potentials appeared in short, irregular bursts. This is not the typical bursting electrical activity seen in rodent islets using classic electrophysiology [19]. It is, however, known that human beta cells display a greater complexity and wider variety of secretagogue-induced electrical activity patterns than rodent beta cells [20]. Nevertheless, it is not possible to draw any conclusions about the typical electrical activity of stimulated human islet cells based only on a few experiments. Figure 2B demonstrates the dynamics of insulin release in one experiment using 25 islets from patient 2 . An increase in insulin release peaking at over $200 \%$ of the average insulin secretion during the first $10 \mathrm{~min}$ of perifusion was achieved with $12 \mathrm{mmol} / \mathrm{l}$ glucose. Whereas $200 \mu \mathrm{mol} /$ 1 diazoxide inhibited release, $25 \mathrm{mmol} / 1 \mathrm{KCl}$ caused a marked increase in hormone secretion. Finally, tolbutamide gave a slight stimulation of insulin secretion. These responses were expected in islets from a subject with normal carbohydrate metabolism.

Patient 3. This patient had unknown glucose tolerance, but normal fasting blood glucose. Figure $3 \mathrm{~A}$ shows an islet from patient 3 that responded with slow oscillations in $\left[\mathrm{Ca}^{2+}\right]_{\mathrm{i}}$ to tolbutamide stimulation. A patch-clamp recording from a putative betacell in an islet from the same patient demonstrated a response to glucose. The cell was depolarized and displayed action potentials. As can be seen in the expanded segment (i) in Figure 3B, there was no bursting electrical activity, but rather a continuous pattern of action potentials with a frequency of $5-6 \mathrm{~Hz}$.

Patient 4. This patient had a normal fasting blood glucose, but a 2 -h blood glucose value during the glucose tolerance test defined her as diabetic. As is seen in Figure 4A, increasing media glucose concentration from 3 to $12 \mathrm{mmol} / 1$ still caused $\left[\mathrm{Ca}^{2+}\right]_{\mathrm{i}}$ to increase, and the islet even displayed a few irregular $\left[\mathrm{Ca}^{2+}\right]_{i-}$ oscillations. The islet responded to depolarization with $\mathrm{KCl}$ with a prominent increase in $\left[\mathrm{Ca}^{2+}\right]_{i}$, as shown in Figure 4B. In Figure 4C, tolbutamide stimulation of the same islet resulted in fairly regular oscillations in $\left[\mathrm{Ca}^{2+}\right]_{i}$ with a period of approximately 3 min. These slow oscillations were true $\mathrm{Ca}^{2+}$-oscillations, as evidenced by antiparallel changes in fluorescence at the two excitation wavelengths, 340 and 380 $\mathrm{nm}$. Superimposed on the slow oscillations in $\left[\mathrm{Ca}^{2+}\right]_{\mathrm{i}}$, however, we observed faster oscillations with a period of approximately $20-30 \mathrm{~s}$. These fast transients did not seem to represent changes in $\left[\mathrm{Ca}^{2+}\right]_{i}$, since the fluorescence changed in a parallel pattern at the two excitation wavelengths. This type of oscillation has not been seen in islets from any other of the more than 15 patients studied by our group. The significance of this observation remains unclear. The question of whether these oscillations are caused by some experimental artefact or indeed represent a biological phenomenon, e.g. oscillations in islet autofluorescence, merits further investigation. Islets from patient 4 responded with insulin release upon stimulation with glucose, $\mathrm{KCl}$ and tolbutamide, as shown in Figure 4D. 
A
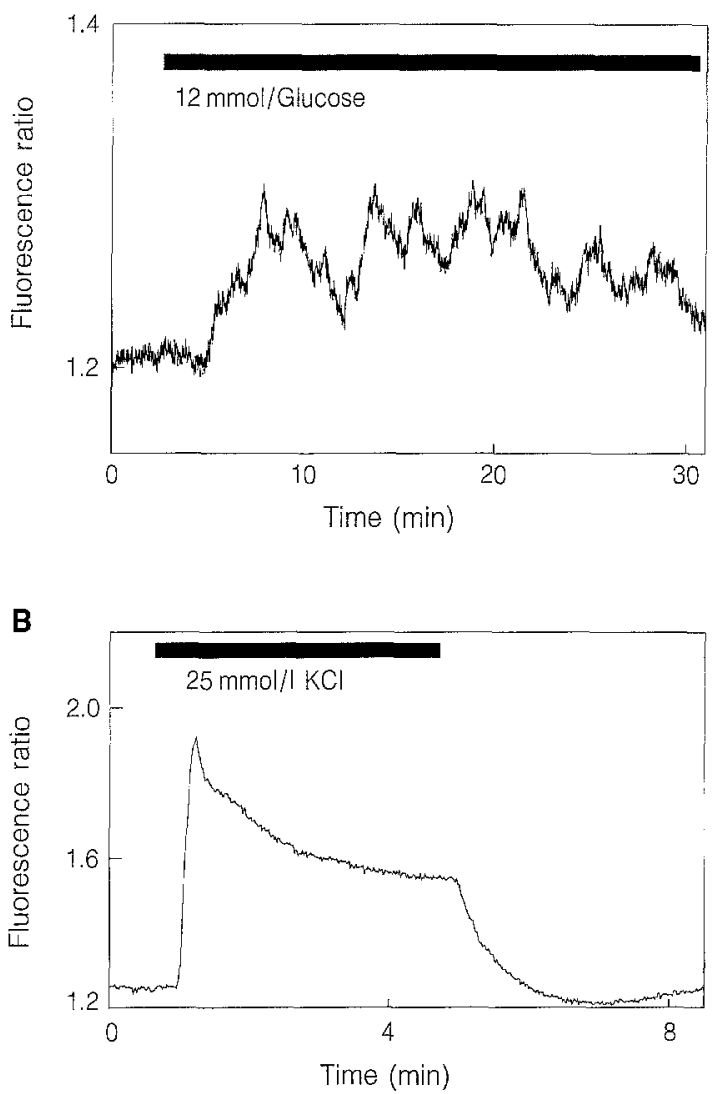

Fig.4A-D. Effects of glucose, $\mathrm{KCl}$ and tolbutamide on $\left[\mathrm{Ca}^{2+}\right]_{\mathrm{i}}$ and insulin release in islets from patient 4 , who had a diabetic glucose tolerance, but normal fasting blood glucose. The "fluorescence ratio" in this figure corresponds to $\left[\mathrm{Ca}^{2+}\right]_{i}$. The islets of this patient were cultured in RPMI 1640 medium containing $5 \mathrm{mmol} / \mathrm{l}$ glucose. A. Islet stimulated with $12 \mathrm{mmol} / \mathrm{l}$ glucose. B. Islet stimulated with $25 \mathrm{mmol} / / \mathrm{KCl}$. C. Islet stimulated with $100 \mu \mathrm{mol} / \mathrm{l}$ tolbutamide. D. Insulin release from 20 islets stimulated with $12 \mathrm{mmol} / /$ glucose, $25 \mathrm{mmol} / \mathrm{l} \mathrm{KCl}$ and $100 \mu \mathrm{mol} / \mathrm{l}$ tolbutamide

$\left.\mathrm{Ca}^{2+}\right]_{i}$ measurements, patients 5 and 6. As can be seen in Figures $5 \mathrm{~A}$ and $\mathrm{B}$, increasing the medium glucose concentration to $10-12 \mathrm{mmol} / 1$ resulted in the appearance of slow $\left[\mathrm{Ca}^{2+}\right]_{\mathrm{i}}$ oscillations, of 2-3 min duration, in islets from patient 5 , who had unknown glucose tolerance but normal fasting blood glucose. Similar oscillations were observed in experiments using islets from a total of six different patients. The duration of these oscillations was in agreement with the duration of $\left[\mathrm{Ca}^{2+}\right]_{\mathrm{i}}$-oscillations in glucose-stimulated rodent islets $[3,21]$.

The appearance of slow $\left[\mathrm{Ca}^{2+}\right]_{\mathrm{i}}$-oscillations (Fig. 5C) was also promoted by $100 \mu \mathrm{mol} / 1$ tolbutamide, with a duration similar to that seen during glucose stimulation (cf Fig. 5A and B). Tolbutamide-induced oscillations were observed in experiments in islets from a total of three patients. Slow oscillations in $\left[\mathrm{Ca}^{2+}\right]_{\mathrm{i}}$, in response to tolbutamide stimulation, have
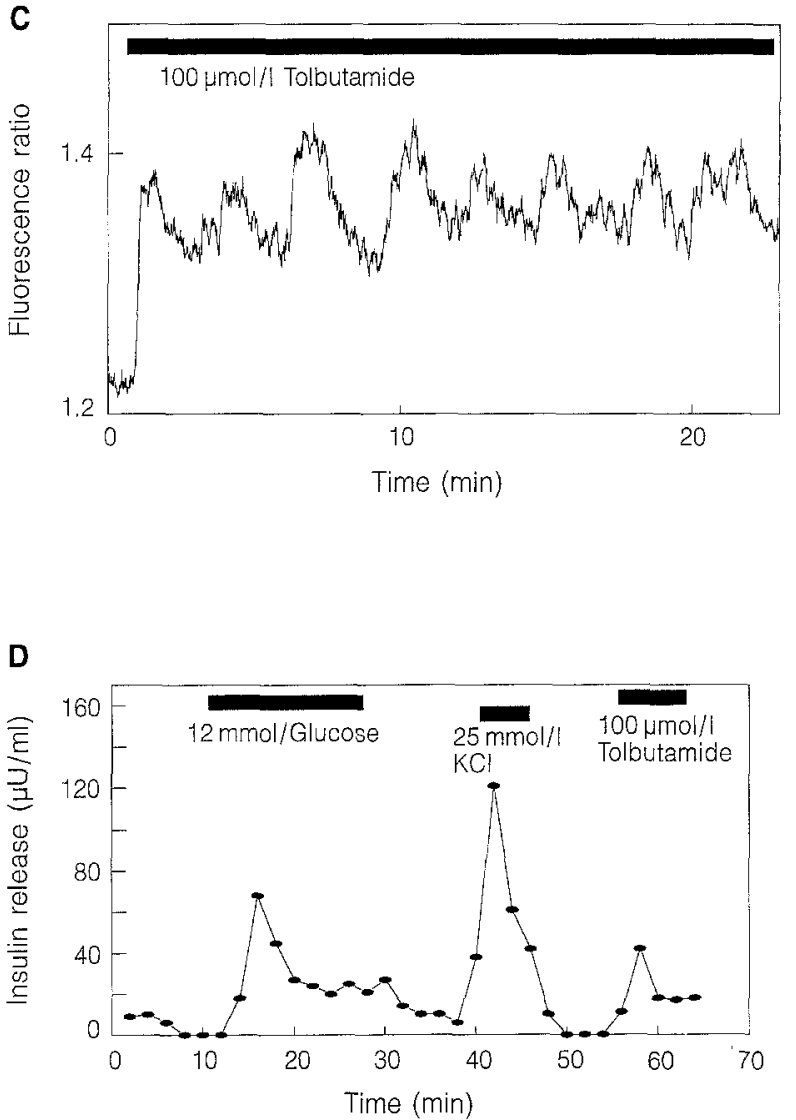

previously been observed in single mouse beta cells [22]. Interestingly, the experiment shown Figure 5C was performed on an islet from a diabetic patient (patient 6). As might be expected, $\left[\mathrm{Ca}^{2+}\right]_{\mathrm{i}}$ did not increase in response to glucose stimulation, but the sulphonylurea drug tolbutamide elicited slow oscillations in $\left[\mathrm{Ca}^{2+}\right]_{\mathrm{i}}$. The initial glucose stimulation of this islet actually caused a small but sustained decrease in $\left[\mathrm{Ca}^{2+}\right]_{i}$, an effect seen transiently with glucose stimulation of fuel-deprived beta cells from normal mice [23].

Many islets stimulated with glucose or tolbutamide displayed a simple, monophasic elevation in $\left[\mathrm{Ca}^{2+}\right]_{\mathrm{i}}$ (data not shown), as previously reported [1]. This could indicate a heterogeneity in the function of the signal-transduction pathways of pancreatic islets, but can also be explained by a difference in the ability of individual islets to withstand the isolation procedure.

Insulin release experiments, patients $7-9$. Figure $6 \mathrm{~A}$ shows the dynamics of insulin release in one experiment using 12 islets from patient 7 , who had normal glucose tolerance. At a glucose concentration of $12 \mathrm{mmol} / \mathrm{l}$ there was only a slight stimulation of insulin release, whereas $\mathrm{KCl}$ caused a marked increase of hormone secretion. In a patient with normal carbohydrate metabolism, a more vigorous response to glucose would have been expected. Finally, tolbutamide increased secretion whereas diazoxide seemed to have no effect. 
A

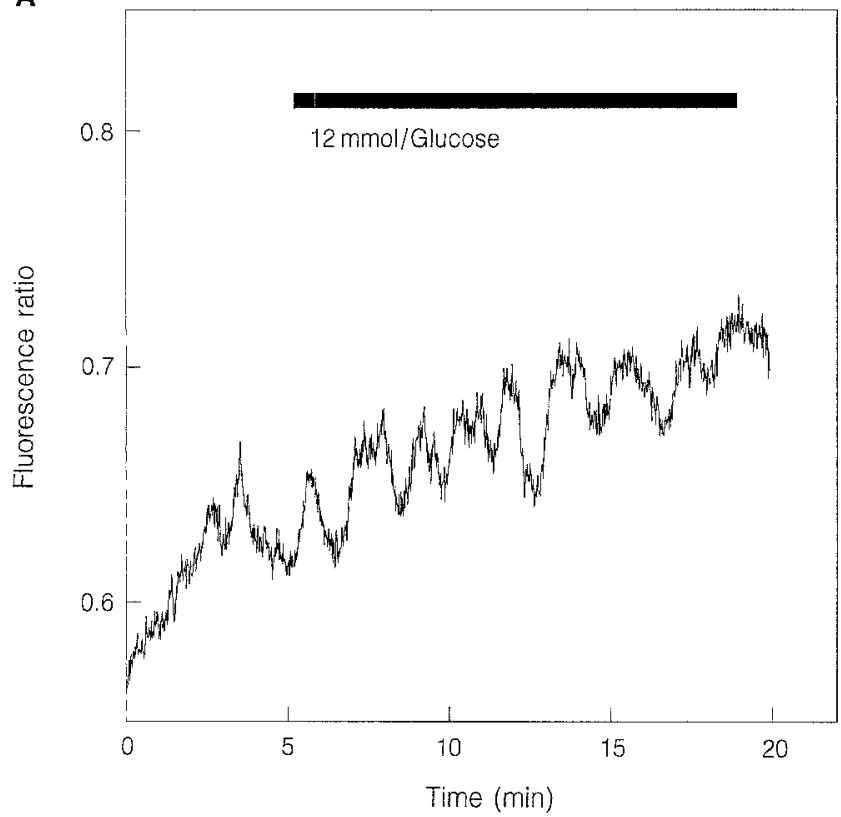

C

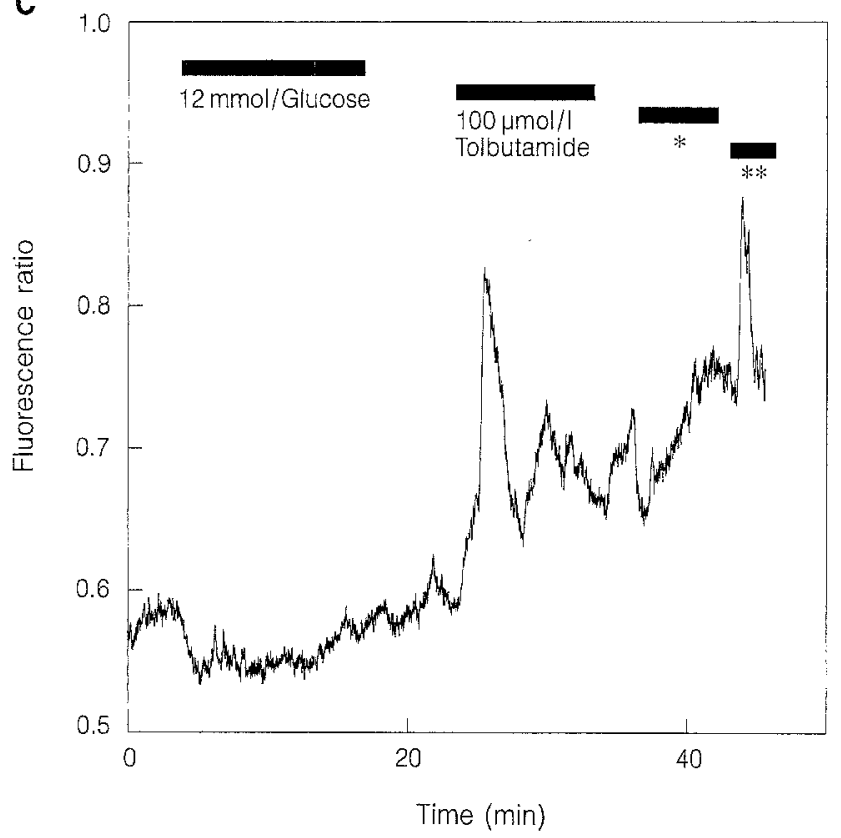

Fig.5A-C. Effects of glucose and tolbutamide stimulation on $\left[\mathrm{Ca}^{2+}\right]_{\mathrm{i}}$ in human pancreatic islets. The "fluorescence ratio" shown in this figure corresponds to $\left[\mathrm{Ca}^{2+}\right]_{\mathrm{i}}$. A. Medium glucose concentration raised from 3 to $12 \mathrm{mmol} / \mathrm{l}$. The islet was from patient 5, who had normal fasting blood glucose. B. Another islet from patient 5. Medium glucose concentration raised from 3 to $11 \mathrm{mmol} / \mathrm{l}$. C. Initial stimulation of an islet from patient 6 , who was diabetic, with $12 \mathrm{mmol} / \mathrm{l}$ glucose only caused a slight decrease in $\left[\mathrm{Ca}^{2+}\right]_{\mathrm{i}}$. Tolbutamide $(100 \mathrm{umol} / \mathrm{l})$ caused $2-3$ slow $\left[\mathrm{Ca}^{2+}\right]_{\mathrm{i}}$ oscillations to occur. ${ }^{*} 100 \mu \mathrm{mol} / \mathrm{h} \mathrm{car-}$ bamyl choline; ** $25 \mathrm{mmol} / \mathrm{KCl}$

Figure $6 \mathrm{~B}$ demonstrates the dynamics of insulin release in one experiment using 17 islets from patient 8 , who had a fasting blood glucose in the diabetic range. At a glucose concentration of $12 \mathrm{mmol} / \mathrm{l}$ there was an

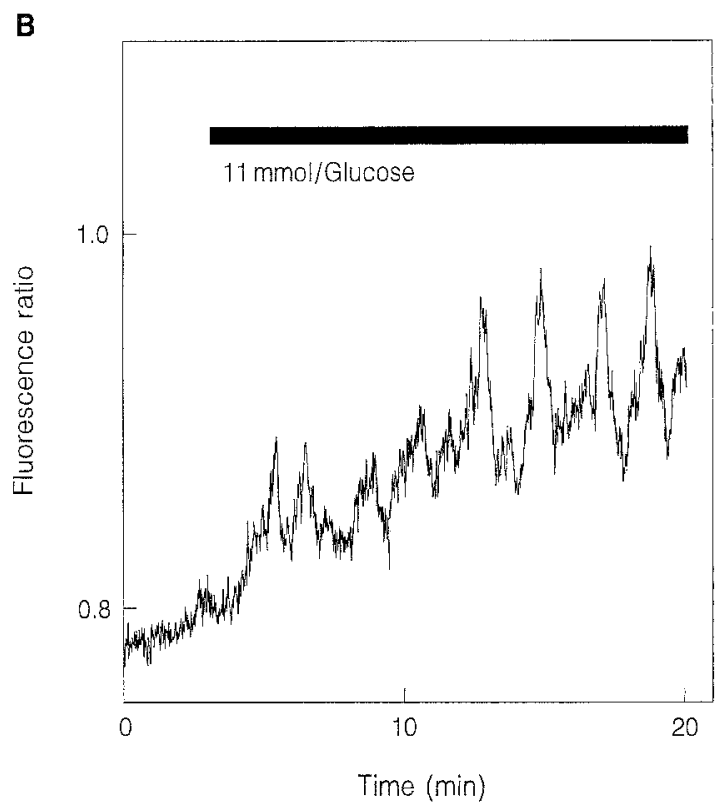

increase in insulin release peaking at approximately $175 \%$ of the average insulin secretion during the first $10 \mathrm{~min}$ of perifusion. In this case, $100 \mu \mathrm{mol} / 1$ diazoxide caused a dramatic inhibition of hormone secretion, which became suppressed to undetectable levels. After discontinuation of diazoxide, insulin release returned to basal levels. $\mathrm{KCl}$ stimulation increased insulin release substantially, an effect which was reversible upon withdrawal of the depolarizing stimulus. Subsequent addition of tolbutamide increased insulin release to some extent.

In Figure 6C the results from an experiment with static incubation of human islets from patient 9 are depicted. It should be noted that this patient had impaired glucose tolerance, although fasting blood glucose was normal. $11 \mathrm{mmol} / \mathrm{l}$ glucose stimulated insulin release to approximately $175 \%$ of basal release, an effect that reached statistical significance. Although $16.7 \mathrm{mmol} / 1$ glucose stimulated insulin release to $155 \%$ of basal, this effect was not statistically significant. The latter was true also for the stimulatory effects of both tolbutamide and glipizide. Glucose-induced insulin release in rodent islets often increases 10 -fold above basal hormone release [24]. The reason why insulin secretion is not as potently activated in the human islets studied in the present report is not clear. Our results, however, are more similar to those of previous studies of human islets [25], showing increases in insulin release of 4-6 times above basal. Generally, the insulin release experiments were carried out on the day following isolation of the islets, excluding a prolonged time in culture as an explanation to the limited insulin response. Overnight culture of islets at $11 \mathrm{mmol} / 1$ glucose does not normally impair insulin release capacity [26]. The experiments concerning insulin release, however, clearly support the notion that the 


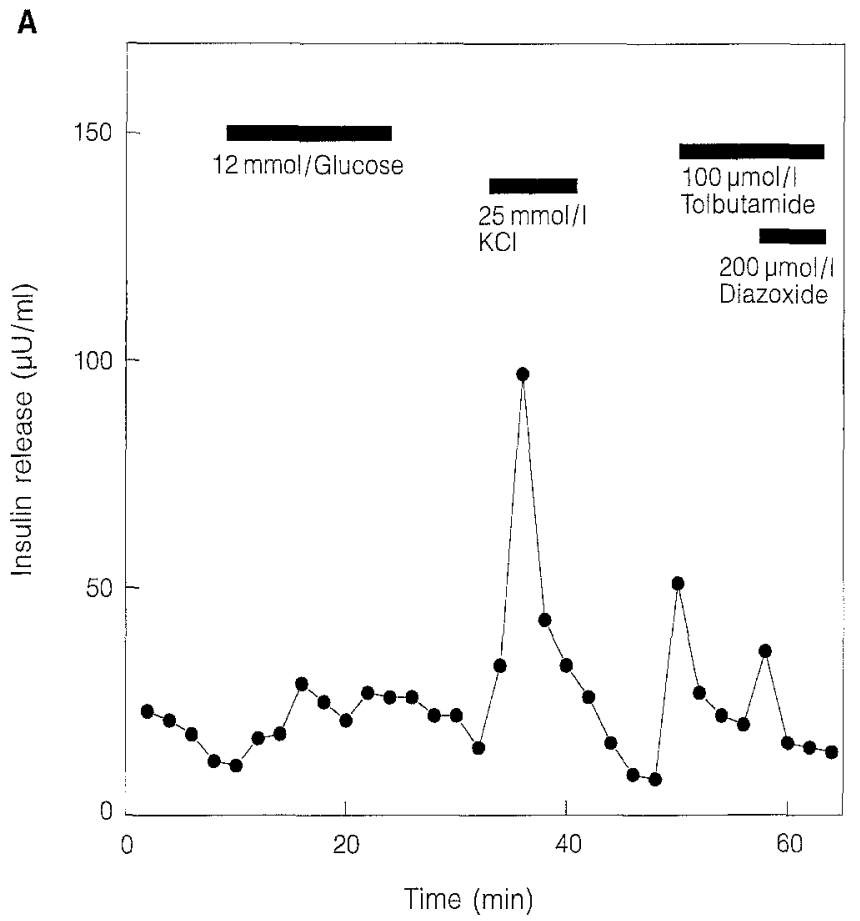

C

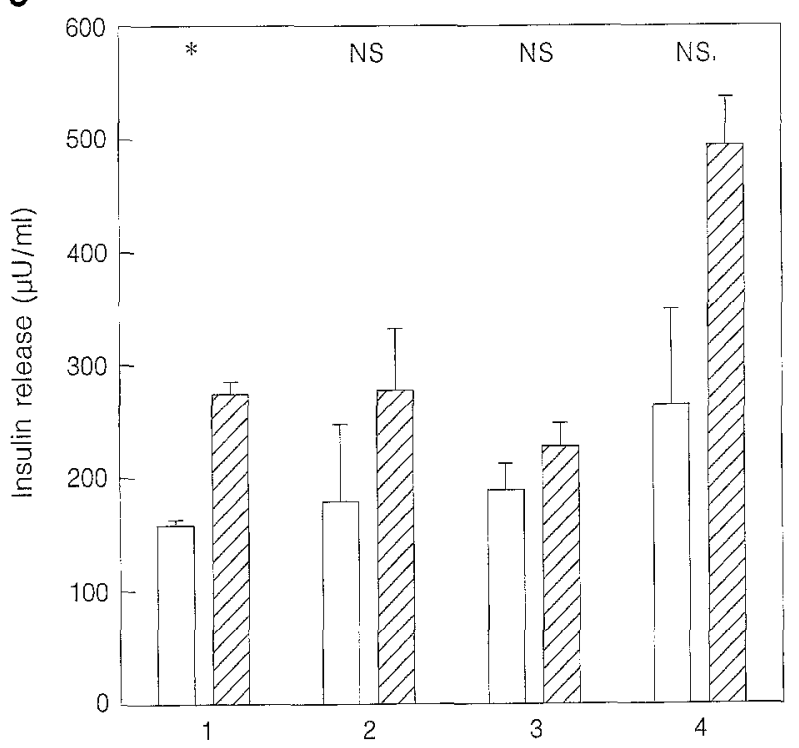

normal beta-cell signal-transduction pathway was qualitatively preserved in our human islet preparations.

\section{Discussion}

In our previous report on secretagogue-induced changes in $\left[\mathrm{Ca}^{2+}\right]_{\mathrm{i}}$ in human pancreatic islets, we presented one experiment in which an increase in medium glucose concentration resulted in slow oscillations in $\left[\mathrm{Ca}^{2+}\right]_{i}[1]$. In the present study we show that slow oscillations in $\left[\mathrm{Ca}^{2+}\right]_{i}$, with $2-3$ min duration, indeed are a characteristic feature of human
B

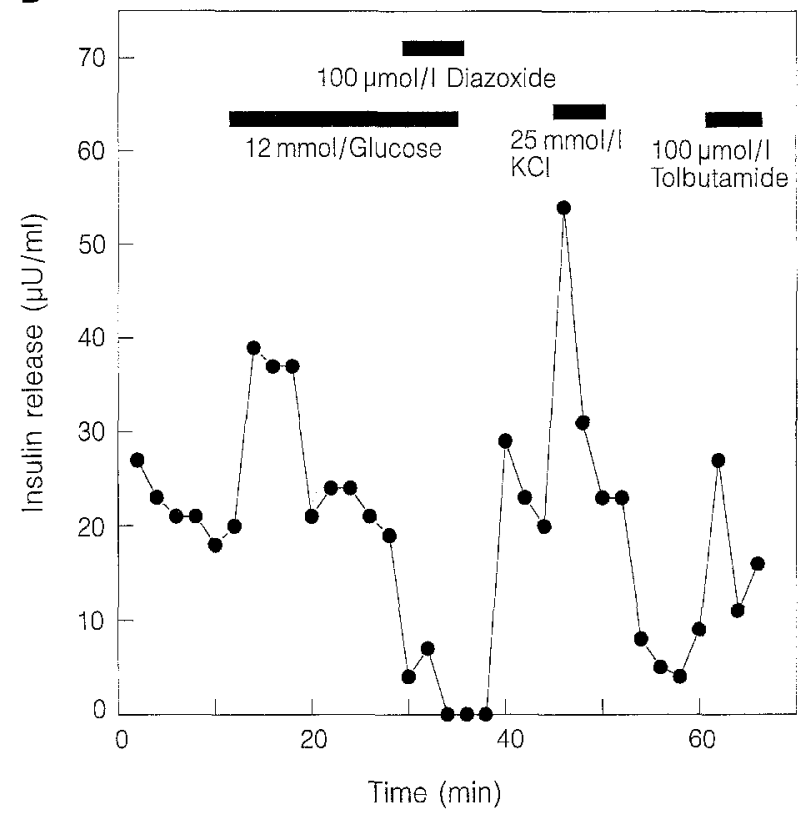

Fig. 6A-C. Effects of glucose, tolbutamide, glipizide, $\mathrm{KCl}$ and diazoxide stimulation on insulin release from human pancreatic islets. A. Dynamics of insulin release from 12 islets from patient 7, who had normal glucose tolerance. An increase in glucose did not affect hormone release. Insulin secretion was potently stimulated by $25 \mathrm{mmol} / \mathrm{KCl}$ whereas $100 \mu \mathrm{mol} / \mathrm{l}$ tolbutamide had a smaller effect. No clear inhibition was seen with $200 \mu \mathrm{mol} / 1$ diazoxide. This experiment was carried out 2 days after isolation of the islets. B. Dynamics of insulin release from 17 islets from patient 8 , who had a fasting blood glucose in the diabetic range. $12 \mathrm{mmol} / \mathrm{l}$ glucose increased insulin release to a peak of $177 \%$ of the average insulin release during the first $10 \mathrm{~min}$. Addition of $100 \mu \mathrm{mol} / \mathrm{l}$ diazoxide resulted in a drastic inhibition of hormone release to undetectable levels. After discontinuation of diazoxide exposure, insulin release returned to basal levels. $\mathrm{KCl}$ stimulation increased insulin release substantially and this effect was reversible upon withdrawal of the depolarizing stimulus. Subsequent tolbutamide addition increased insulin release to some extent. C. Static incubation of human islets from patient 9 with various stimuli. Patient 9 had normal fasting blood glucose, but impaired glucose tolerance. Basal insulin release at $3 \mathrm{mmol} / \mathrm{l}$ glucose $(\square)$, stimulated insulin release (娄). A $75 \%$ increase in insulin secretion was caused by $11 \mathrm{mmol} / \mathrm{l}$ glucose (1). $16.7 \mathrm{mmol} / 1$ glucose resulted in an approximately $55 \%$ increase of hormone release (2); whereas $100 \mu \mathrm{mol} / \mathrm{l}$ tolbutamide (3) only increased insulin secretion slightly above normal. Finally, $3 \mu \mathrm{mol} / \mathrm{l}$ glipizide stimulated insulin release by approximately $87 \%$ above basal release (4). Each bar represents average secretion \pm SEM from three groups of islets, each consisting of 5 islets. Statistical significances determined by Student's $t$-test for unpaired data " $p<0.05$

pancreatic islets, when stimulated with both glucose (10-12 mmol/l) and tolbutamide $(100 \mu \mathrm{mol} / \mathrm{l})$. These oscillations correspond well to glucose-induced oscillations in $\left[\mathrm{Ca}^{2+}\right]_{\mathrm{i}}$ in rodent single beta cells and beta-cell-clusters $[14,27,28]$, to tolbutamide-induced oscillations in $\left[\mathrm{Ca}^{2+}\right]_{i}$ in rodent beta cells [22] and to slow glucose-induced oscillations in $\left[\mathrm{Ca}^{2+}\right]_{\mathrm{i}}$ in 
intact rodent islets $[3,21]$. It has been demonstrated that insulin secretion from isolated mouse islets is pulsatile and synchronized with bursts of electrical activity [29], and probably also with oscillations in $\left[\mathrm{Ca}^{2+}\right]_{\mathrm{i}}[30,31]$. Previous studies have shown impaired or irregular pulsatile secretion of insulin in NIDDM patients [32] and in minimally glucose-intolerant first degree relatives of NIDDM patients [11]. It is tempting to speculate that this disturbed pattern of pulsatile hormone release corresponds to a similarly affected pattern of electrical activity and $\left[\mathrm{Ca}^{2+}\right]_{i-}$ oscillations. The present study demonstrates that glucose-induced oscillations in $\left[\mathrm{Ca}^{2+}\right]_{\mathrm{i}}$ can be seen in islets from a subject with impaired glucose tolerance. Possibly there is some functional heterogeneity of the pancreatic islets in persons with impaired glucose tolerance, with some islets displaying normal oscillations in $\left[\mathrm{Ca}^{2+}\right]_{\mathrm{i}}$ and others having a disturbed oscillatory pattern. Functional heterogeneity has been demonstrated in individual beta cells [33]. Moreover, the extent to which oscillations in $\left[\mathrm{Ca}^{2+}\right]_{\mathrm{i}}$ are directly linked to pulsatile insulin secretion is still not clear. Hence, it is not unlikely that despite intact $\left[\mathrm{Ca}^{2+}\right]_{i}$ oscillations, the downstream signal for exocytosis is impaired. In view of the limited number of islets studied, it is not possible to draw conclusions about possible important quantitative differences in islet response.

It is interesting to note that tolbutamide mimics not only the qualitative effects of glucose on $\left[\mathrm{Ca}^{2+}\right]_{i}$ in islets, but also mimics the dynamics of glucose-induced changes in $\left[\mathrm{Ca}^{2+}\right]_{\mathrm{i}}$. Thus, stimulation with sulphonylurea induces a similar type of $\left[\mathrm{Ca}^{2+}\right]_{i}$-oscillations as does glucose in human pancreatic islets. Tolbutamide-induced slow $\left[\mathrm{Ca}^{2+}\right]_{\mathrm{i}}$-oscillations are seen even in a diabetic patient. If $\left[\mathrm{Ca}^{2+}\right]_{i}$-oscillations are directly translated into pulsatile insulin release, this means that sulphonylurea treatment of NIDDM patients could be expected to restore the normal dynamics of insulin secretion.

The observation that glucose-stimulation of an islet from a diabetic patient actually caused a sustained decrease in $\left[\mathrm{Ca}^{2+}\right]_{\mathrm{i}}$ is interesting. It has previously been shown in diabetic subjects that glucose infusion causes a paradoxical decrease in plasma insulin levels [34]. In normal, fuel-deprived rodent beta cells, glucose stimulation also gives rise to an initial decrease in $\left[\mathrm{Ca}^{2+}\right]_{\mathrm{i}}$, which is followed by a sustained increase in $\left[\mathrm{Ca}^{2+}\right]_{i}[23]$. The initial decrease in $\left[\mathrm{Ca}^{2+}\right]_{\mathrm{i}}$ subsequent to glucose utilization probably reflects an increased plasma membrane $\mathrm{Ca}^{2+}$-pump activity and intracellular $\mathrm{Ca}^{2+}$-sequestration, due to an increase in the availability of ATP. In pancreatic islets from diabetic patients the coupling between increased energy production and lowering in $\left[\mathrm{Ca}^{2+}\right]_{i}$ seems to be intact, whereas the coupling between the increased energy level and closure of $\mathrm{K}_{\mathrm{ATP}}$-channels does not operate properly.
The present report demonstrates the first patchclamp recordings of the electrical activity of betacells in situ in human pancreatic islets. The bursting pattern of electrical activity, which is typical of glucose-stimulated beta-cells in rodent islets, was not observed under the present experimental conditions, although irregular bursts upon tolbutamide stimulation were noted. Possibly, the patch-clamp experimental technique itself affects the beta cell and disturbs the pattern of electrical activity. Most cells from which patch-clamp recordings were made, were first partly mechanically dissociated from their neighbouring cells. This manoeuver possibly disturbed the electrical response pattern by affecting both the electrical activity of individual beta-cells and by attenuating cell-to-cell interactions. Furthermore, the patchclamp experiments were carried out at a temperature of $30-34^{\circ} \mathrm{C}$, which could affect the pattern of electrical activity. Also, even though the majority of islet cells are beta cells, we cannot exclude that some of the cells studied with the patch-clamp technique in the present study were non-beta cells. In mouse islets, the bursting electrical activity has been shown to directly correspond to $\left[\mathrm{Ca}^{2+}\right]_{i}$ oscillations of similar frequency, 2-6 $\mathrm{min}^{-1}$ [4]. Interestingly, we did not observe any such fast $\left[\mathrm{Ca}^{2+}\right]_{\text {- }}$-oscillations in the human islets, suggesting that bursting electrical activity either does not usually occur in human islets, or that the electrical activity of different islet domains is unsynchronized. More definite conclusions concerning human beta-cell electrical activity must await detailed recordings of membrane potential using classic electrophysiology.

Many individual islets from the various patients in the present study did not respond to any stimulus. Even in patients classified as having normal glucose tolerance after an oral glucose tolerance test in the present study, some islets responded to glucose, whereas other islets did not (data not shown). This suggests heterogeneity in the function of individual human pancreatic islets and/or in the ability of individual islets to withstand the isolation procedure. Since the islets were obtained from a region of the pancreas in close proximity to the pancreatic tumour, some islets may have been exposed to increased local tissue pressure and elevated levels of inflammatory mediators in situ, factors possibly interfering with islet function. In this context it must also be remembered that isolated islets have had their normal neural connections severed and thus possibly important neurotransmitter modulation of beta cell responses is inhibited. Cholinergic [35], galaninergic [36] and adrenergic [37] stimuli affect the membrane potential of glucose-stimulated beta-cells and could thus modulate oscillations in electrical activity and $\left[\mathrm{Ca}^{2+}\right]_{\mathrm{i}}$. Lack of important modulatory factors may affect different islets to a varying extent and give rise to functional heterogeneity in vitro. 
We can only speculate on the possibility that oscillations in $\left[\mathrm{Ca}^{2+}\right]_{\mathrm{i}}$ are coupled to pulsatile insulin release at the level of the single human islet. Oscillations in insulin secretion, with a duration of 1.5-3 min, have, however, been observed in single mouse islets $[29,30,31,38]$. Also, synchronized oscillations in insulin release have been observed in previous studies in large groups of rat islets [21] and in adenomatous human beta cells [39]. In the present study of intact human islets, the sampling time in the dynamic insulin release experiments is too long to allow any conclusion on possible pulsatility of insulin release, with a duration corresponding to the oscillations in $\left[\mathrm{Ca}^{2+}\right]_{\mathrm{i}}$.

Acknowledgements. We thank Ms. Y. Strömberg and Ms. T. Zeccarias for expert technical assistance with the radioimmunological measurements of insulin. Financial support was obtained from the Swedish Medical Research council (03X09890, 04X-09891 and 19X-00034), the Bank of Sweden Tercentenary Foundation, the Swedish Diabetes Association, the Nordic Insulin Foundation, Magnus Bergvalls Foundation, Novo Industry, Funds of the Karolinska Institute, Förenade Liv Mutual Group Life Insurance Company and the Swedish Society for Medical Research.

\section{References}

1. Kindmark H, Köhler M, Nilsson T et al. (1991) Measurements of cytoplasmic free $\mathrm{Ca}^{2+}$ concentration in human pancreatic islets and insulinoma cells. FEBS Lett 291: 310314

2. Misler S, Barnett DW, Pressel DM, Gillis KD, Scharp DW, Falke LC (1992) Stimulus-secretion coupling in $\beta$-cells of transplantable human islets of Langerhans. Diabetes 41 : $662-670$

3. Valdeolmillos M, Santos RM, Contreras D, Soria B, Rosario LM (1989) Glucose-induced oscillations of intracellular $\mathrm{Ca}^{2+}$ concentration resembling bursting electrical activity in single mouse islets of Langerhans. FEBS Lett 259: 19-23

4. Santos RM, Rosario LM, Nadal A, Garcia-Sancho J, Soria B, Valdeolmillos M (1991) Widespread synchronous $\left[\mathrm{Ca}^{2+}\right]_{\mathrm{i}}$ oscillations due to bursting electrical activity in single pancreatic islets. Pflügers Arch 418: 417-422

5. Matthews DR, Lang DA, Peto J, Turner RC (1978) Cyclical variation (Hunting) of basal plasma glucose and insulin concentrations in normal and diabetic man. Diabetologia 15: 254-263

6. Lang DA, Matthews DR, Peto J, Turner RC (1979) Cyclic oscillations of basal plasma glucose and insulin concentrations in human beings. N Eng J Med 301: 1023-1027

7. Efendic S, Kindmark H, Berggren P-O (1991) Mechanisms involved in the regulation of the insulin secretory process. $J$ Int Med 229: 9-22

8. Matthews DR, Naylor BA, Jones RG, Ward GM, Turner RC (1983) Pulsatile insulin has greater hypoglycemic effect than continuous delivery. Diabetes 32: 617-621

9. Bratusch-Marrain PR, Komjati M, Waldhäusl WK (1986) Efficiency of pulsatile versus continuous insulin administration on hepatic glucose production and glucose utilization in type 1 diabetic human subjects. Diabetes 35: 922-926

10. Stagner JI, Samols E, Weir GC (1980) Sustained oscillations of insulin, glucagon and somatostatin from the isolat- ed canine pancreas during exposure to a constant glucose concentration. J Clin Invest 65: 939-942

11. O,Rahilly S, Turner RC, Matthews DR (1988) Impaired pulsatile secretion of insulin in relatives of patients with non-insulin-dependent diabetes. N Eng J Med 318: 12251230

12. Keen H, Jarret RJ, McCartney P (1982) The ten-year follow-up of the Bedford Survey (1962-1972): glucose tolerance and diabetes. Diabetologia 22:73-78

13. Hellman B (1975) The significance of calcium for glucose stimulation of insulin release. Endocrinology 97: 392-398

14. Kindmark H, Köhler M, Efendic S, Rorsman P, Larsson O, Berggren P-O (1992) Protein kinase C activity affects glucose-induced oscillations in cytoplasmic free $\mathrm{Ca}^{2+}$ in the pancreatic B-cell. FEBS Lett 303: 85-90

15. Hamill OP, Marty A, Neher E, Sakmann B, Sigworth FJ (1981) Improved patch-clamp techniques for high-resolution current recordings from cells and cell-free membrane patches. Pflügers Arch 391: 85-100

16. Horn DR, Marty A (1988) Muscarinic activation of ionic currents measured by a new whole-cell recording method. J Gen Physiol 92: 145-159

17. Kanatsuna T, Lernmark $\AA$, Rubenstein AH, Steiner DF (1981) Block in insulin release from column-perifused pancreatic beta-cells induced by islet-cell surface antibodies and complement. Diabetes 30: 231-234

18. Arkhammar P, Nilsson T, Rorsman P, Berggren P-O (1987) Inhibition of ATP-regulated $\mathrm{K}^{+}$channels precedes depolarization-induced increase in cytoplasmic free $\mathrm{Ca}^{2+}$ concentration in pancreatic beta-cells. J Biol Chem 262: $5448-$ 5454

19. Henquin JC, Meissner HP (1984) Significance of ionic fluxes and changes in membrane potential for stimulus-secretion coupling in pancreatic beta-cells. Experientia 40: 1043-1052

20. Misler S, Barnett DW, Gillis KD, Pressel DM (1992) Electrophysiology of stimulus-secretion coupling in human beta-cells. Diabetes 41: 1221-1228

21. Longo EA, Tornheim K, Deeney JT et al.(1991) Oscillations in cytosolic free $\mathrm{Ca}^{2+}$, oxygen consumption, and insulin secretion in glucose-stimulated rat pancreatic islets. J Biol Chem 266: 9314-9319

22. Grapengiesser E, Gylfe E, Hellman B (1990) Sulfonylurea mimics the effect of glucose in inducing large amplitude oscillations of cytoplasmic $\mathrm{Ca}^{2+}$ in pancreatic beta-cells. Mol Pharm, 37: 461-467

23. Nilsson T, Arkhammar P, Berggren P-O (1988) Dual effect of glucose on cytoplasmic free $\mathrm{Ca}^{2+}$ concentration and insulin release reflects the beta-cell being deprived of fuel. Biochem Biophys Res Comm 153: 984-991

24. Lernmark $\AA$. (1974) The preparation of, and studies on, free cell suspensions from mouse pancreatic islets. Diabetologia 10: 431-438

25. Grant AM, Christie MR, Ashcroft SJH (1980) Insulin release from human pancreatic islets in vitro. Diabetologia 19: $114-117$

26. Östensson C-G, Khan A, Abdel-Halim SM et al. (1993) Abnormal insulin secretion and glucose metabolism in pancreatic islets from the spontaneously diabetic $9 \mathrm{~K}$ rat. Diabetologia 36: 3-8

27. Grapengiesser E, Gylfe E, Hellman B (1988) Glucose-induced oscillations of cytoplasmic $\mathrm{Ca}^{2+}$ in the pancreatic beta-cell. Biochem Biophys Res Comm 151: 1299-1304

28. Wang J-L, McDaniel ML (1990) Secretagogue-induced oscillations of cytoplasmic $\mathrm{Ca}^{2+}$ in single $\beta$ and $\alpha$-cells obtained from pancreatic islets by fluorescence-activated cell sorting. Biochem Biophys Res Comm 166: 813-818 
29. Rosario LM, Atwater I, Scott AM (1986) Pulsatile insulin release and electrical activity from single ob/ob mouse islets of Langerhans. Adv Exp Med Biol 211: 413-425

30. Gilon P, Shepherd RM, Henquin J-C (1993) Oscillations of secretion driven by oscillations of cytoplasmic $\mathrm{Ca}^{2+}$ as evidenced in single pancreatic islets. J Biol Chem 268: 2226522268

31. Bergsten P, Grapengiesser E, Gylfe E, Tengholm A, Hellman B (1994) Synchronous oscillations of cytoplasmic $\mathrm{Ca}^{2+}$ and insulin release in glucose-stimulated pancreatic islets. J Biol Chem 269: 8749-8753

32. Lang DA, Matthews DR, Burnett M, Turner RC (1981) Brief, irregular oscillations of basal plasma insulin and glucose concentrations in diabetic man. Diabetes 30: 435-439

33. Pipeleers D (1987) The biosociology of pancreatic B-cells. Diabetologia 30: 277-291

34. Hellman B, Berne C, Grapengiesser E, Grill V, Gylfe E, Lund P-E (1990) The cytoplasmic $\mathrm{Ca}^{2+}$ response to glucose as an indicator of impairment of the pancreatic $\beta$-cell function. Eur J Clin Invest 20: [Suppl 1]: S10-17
35. Ämmälä C, Larsson O, Berggren P-O et al. (1991) Inositol trisphosphate-dependent periodic activation of a $\mathrm{Ca}^{2+}-\mathrm{ac}-$ tivated $\mathrm{K}^{+}$conductance in glucose-stimulated pancreatic $\beta$-cells. Nature 353: 849-852

36. Ashcroft FM, Rorsman P (1989) Electrophysiology of the pancreatic $\beta$-cell. Prog Biophys Molec Biol 54: 87-143

37. Nilsson T, Arkhammar P, Rorsman P, Berggren P-O (1988) Inhibition of glucose-stimulated insulin release by $\alpha_{2}$-adrenoceptor activation is paralleled by both a repolarization and a reduction in cytoplasmic free $\mathrm{Ca}^{2}+$ concentration. $\mathrm{J}$ Biol Chem 263: 1855-1860

38. Bergsten P, Hellman B (1993) Glucose-induced amplitude regulation of pulsatile insulin secretion from individual pancreatic islets. Diabetes 42: 670-674

39. Chou H-F, Ipp E, Bowsher RR, Berman N, Ezrin C, Griffiths $S$ (1991) Sustained pulsatile insulin secretion from adenomatous human $\beta$-cells. Diabetes 40: 1453-1458 